\title{
CJLT

\section{From First Life to Second Life: Evaluating task-based language learning in a new environment \\ De la vie réelle à la vie virtuelle: évaluation de l'apprentissage des langues basé sur les tâches dans un nouvel environnement}

Min Jung Jee, University of Texas at Austin

\begin{abstract}
With its growing number of users, Second Life as one of the avatar-based 3D virtual worlds has received attention from educators and researchers in various fields to explore its pedagogical benefits. Given the increasing implementation of technologies broadly in much instruction, this study investigated how ESL students negotiated meanings in Second Life while using the features of Second Life. Enrolled in a university ESL program, 34 high- and low-intermediate students participated. In order to investigate a new function of Second Life, students were asked to use the voice-chat function and communication features of avatars as they participated in three task types: Jigsaw, Decision-making, and Discussion tasks, representing the continuum of communicative tasks by Pica, Kanagy, and Falodun (1993). Negotiation of meaning model by Varonis and Gass (1985) was used as the main construct to analyze students' language use. Phenomena emerging from the data pointed to the utility of a sociocultural approach and led to a focus on patterns of negotiation of meaning as differentially elicited in different task types and on an in-depth analysis of the students' collaborations with their group members in Second Life.
\end{abstract}

Key words: Second Life, Synchronous Computer-Mediated Communication, Task-based instruction, Second Language Acquisition

\section{Résumé}

« Second Life » est un univers virtuel en 3D basé sur des avatars qui a récemment retenu l'attention des éducateurs et des chercheurs de divers domaines, désireux d'explorer les avantages pédagogiques de ce jeu. Étant donné l'application croissante des technologies en éducation, cette étude a examiné la manière dont différents types de tâches affectent l'utilisation de l'environnement «Second Life » chez les étudiants d'anglais langue seconde (ALS), et les facteurs déterminant le succès ou l'échec dans l'exécution d'une tâche. 34 étudiants universitaires inscrits dans des programmes intermédiaires d'ALS de niveaux différents ont été invités à 
utiliser les fonctions de conversation orale (chat vocal) et de communication des avatars alors qu'ils participaient à trois types de tâches: casse-tête, prise de décision, et tâches de discussion, correspondant à l'éventail des tâches communicatives de Pica, Kanagy et Falodun (1993). Les données montrent de façon provisoire comment les d'étudiants d'ALS de différents niveaux ont utilisé l'environnement « Second Life » dans des types variés de tâches, en mettant l'accent sur l'utilisation des avatars, la téléprésence et les affordances, et révèlent les facteurs cruciaux qui ont conduit au succès ou à l'échec dans l'exécution des tâches.

\section{Introduction}

In response to the call for educators to use technology in various educational disciplines, innovative teaching and learning methods using various types of technology have been developed, and this has led to an improvement of instruction in many academic fields. As one of 3-D multiuser virtual environments (MUVE)s, Second Life has caught educators' and researchers' attention since its launching in 2003 with user-generated and community-oriented features. Moreover, it is currently the most popular and notable 3D MUVE in education (Dickey, 2011), and many universities have developed virtual campuses with Second Life (Schiller, 2009). The number of empirical studies of Second Life has increased since 2006 (Wang \& Burton, 2012), and have reported the benefits of Second Life such as lowering anxiety, enhancing motivation and engagement, facilitating collaboration and social interactions, and increasing a sense of shared presence and experience (Craig, 2007; Dede, Clarke, Ketelhut, Nelson, \& Bowman, 2005; FitzGerald, 2007; Lamb, 2006; New Media Consortium and EDUCAUSE Learning Initiative, 2007). Recently, potential benefits of Second Life for second language acquisition (SLA) has been emphasized, such as enhancing motivation, increasing social presence, providing opportunities for meaningful learning experiences, promoting peerscaffolding, and enhancing learner autonomy (Barab, Thomas, Dodge, Carteaux, \& Hakan, 2005; Dalgarno, 2002; Dickey, 2005; Peterson, 2010, 2012). However, because Second Life was not originally developed for educational purposes, some researchers have also warned about its potential use for virtual harassment, shootings, sexist, racist, and offensive avatar behaviors, and have suggested teachers use Second Life with caution (Bugeja, 2007). Moreover, technical difficulties and insufficient training have been reported as major drawbacks in the use of Second Life (Jee, 2010; Cooke-Plagwitz, 2008; Hislope, 2008; Peterson, 2010; Wang, Lefaiver, Wang, $\&$ Hunt, 2011). In addition, in the field of foreign and second language education, studies have mainly focused on suggesting ways to use Second Life (Cooke-Plagwitz, 2008; Hislope, 2008; Hismanoglu, 2012; Kuriscat \& Luke, 2009; Sykes, Oskoz, \& Thorne, 2008). Even among empirical studies, there has been little research about the effect of task type on students' negotiation of meaning in Second Life. Considering that negotiation of meaning and tasks play important roles in generating students' input and output, and that the special interface of Second Life such as avatar use may contribute to students' learning (Gerhard, Moore, \& Hobbs, 2004; Ornberg, 2003), there is a need for a study on students' negotiation of meaning in Second Life while completing different task types. Thus, the purpose of the present study is to explore how different task types affect high-intermediate and low-intermediate ESL students' negotiation of meaning in Second Life, and how the students used the Second Life environment in task completion. 


\section{Literature Review}

\section{Negotiation of Meaning in SCMC}

Negotiation of meaning has been considered important in SLA because it helps learners to achieve "comprehensible input" and to produce "pushed out" language, both critical elements in language acquisition. Concerning negotiation of meaning in a task-based synchronous computermediated communication (SCMC) instruction, Pellettieri (2000) focused on negotiation routines and linguistic modifications while learners were engaging in five communication tasks from focused open conversation to more closed tasks and concluded that SCMC chats allowed learners to negotiate meanings over all aspects of the discourse and pushed them to form-focused linguistic modifications. Blake's (2000) study showed that jigsaw tasks, that is, tasks that can be solved only when group members pool their information, elicited more negotiation of meaning than information gap tasks, that is, tasks that can be solved by group members who have different information. In the study, lexical confusions were the predominant triggers, suggesting that jigsaw tasks might be better for allowing form-focused instruction. Smith's (2003) study focused on the effect of task types and negotiation in SCMC using the model by Varonis and Gass (1985). He also found that one-third of total turns were negotiation, and the predominant triggers were lexical problems. He concluded that the decision-making tasks, in which team members decide on the best solution after exchanging opinions, elicited more turns than jigsaw tasks, contrary to the previous studies (Pica, Kanagy, \& Falodun, 1993; Blake, 2000). In fact, jigsaw tasks elicited more incidental negotiation, and the decision-making tasks elicited more negotiation sequences. The results can be interpreted by the notion of task-induced saliency (Smith, 2003), that more involvement elicits better retention for unknown words (Laufer \& Hulstijin, 2001). Thus, the words that students remembered most were from the task on which students spent more time with negotiation of meaning. In another study, Smith (2004) stated that learners' retention of the previously unknown words that had been the focus of negotiation was much better than those that were not negotiated.

The findings of the previous studies support the notion that SCMC environments can elicit conversational patterns similar to face-to-face oral communication. Moreover, lexical problems elicited the most negotiation of meaning. In terms of task type, it remains controversial as to which task type promotes more negotiation of meaning. However, as Smith (2003) stated, taskinduced saliency could well explain this phenomenon because what encourages learners to engage and actively be involved in a task for better retention is not task type, but the task difficulty or the content of task. In addition, as Pellettieri (2000) suggested, task difficulty could play a critical role in terms of learners' negotiation. If more difficulties are caused by lack of knowledge about the content of the task, especially lexicon items, more communication breakdowns would occur so that learners would have more negotiation, which ultimately would lead to better retention in memory.

\section{Second Life in SLA}

Second Life is a 3D user-generated virtual environment where users can communicate via their avatars. It is divided into Regions, and avatars can move within a Region and to a different Region by "teleporting." Users can select their avatars (either human-like or non-human like) 
and change its appearance. Moreover, avatars can display a range of movements and emotions such as walking, running, flying, crying, and laughing (for more explanation, see Wigham \& Chanier, 2013; Ventrella, 2011). With the avatars, users can also have a sense of being together in cyber space, or telepresence (Schroeder, 2002), and avatars can converse with each other within a 60-meter radius in the virtual world. Thus, if avatars are close to each other, their voices become louder (Wigham \& Chanier, 2013).

Recently, studies of Second Life have been published in the SLA field. Most of the earlier literature focused on suggestions for better use of Second Life, such as providing simulated roles and identities for enhancing emotional connections and for low-risk practice (Sykes et al., 2008), incorporating external media sources such as webpages, PowerPoint presentations, and videos (Cooke-Plagwitz, 2008; Kemp \& Livingstone, 2006), and offering a venue for communicating in active and meaningful ways (Grant \& Huang, 2010).

In empirical tests of the effectiveness of Second Life, Hislope (2008) reported perceived benefits and drawbacks of using Second Life based on a questionnaire administered. For benefits, students agreed that Second Life allowed them to have more conversational opportunities and cultural experiences than the traditional classroom. For drawbacks, they pointed out technical difficulties. Kuriscak and Luke (2009) also investigated learner attitudes toward Second Life with Spanish L2 learners, using a survey after students had had ten open-ended chats either with their classmates or with native speakers (NSs) of Spanish. Students who had discussions with NSs more strongly agreed that computers can be beneficial for learning another language. Again, students who interacted with NSs showed positive attitudes toward Second Life. Their research supports the view that features of Second Life, one of which is to allow students to interact with NSs, have a positive impact on learning. In a similar vein, Jee (2010) investigated students' attitude toward Second Life using surveys and interviews, and reported that low-intermediate students tended to have more positive attitude toward Second Life than high-intermediate students. She concluded that other factors such as age and level of task difficulty may affect students' attitude. Moreover, technical troubleshooting and clear instruction emerged as prerequisites for better communication. In another study, Jee (2011) explored ESL students' interaction during pre- and post-task periods, and found emerging themes for prerequisites of task completion. She suggested that those features such as solving technical problems and setting Telepresence (Schroeder, 2002) may explain the uniqueness of Second Life interface in determining factors of task success. Deutschmann, Panich, and Molka-Danielsen (2009) investigated students' interactions in terms of floor space, turn lengths, and turn-taking patterns in two oral proficiency courses in a life-long learning program in Second Life. In four 90-minute sessions, variables affecting meaningful task design including authenticity and collaboration were observed. They also insisted that technical and social initiations should be considered in course design. Sykes's (2009) study, based on interview data and in-class presentations, investigated the interlanguage pragmatic development of Spanish learners by focusing on making appropriate requests in Spanish. Although there was little improvement from pre- to posttest, anecdotal evidence suggested that synthetic immersive environment helped students to increase awareness of complicated pragmatic issues and subtleties of making appropriate requests. A study by Henderson, Huang, Grant, and Handerson (2009) reported that self-efficacy ratings of the students learning Chinese had been increased after collaborative activities in Second Life. Moreover, in a Chinese course where Second Life activities were incorporated into a regular face-to-face classroom instruction, Chen (2010) had mixed results about learning 
experience from the students' perspectives. From the instructor's perspective, however, Second Life was a good learning environment. In a study by Wang et al. (2011), most of the studentteachers were positive about the use of Second Life as an EFL learning platform, but they also pointed out technical training or instruction as the main problem, citing the steep learning curve for using Second Life. Peterson's (2010) study investigated students' interaction patterns and strategy use while they were engaged in three tasks. Students showed highly learner centered interaction and used transactional and interaction strategies for effective interaction, which were evidence of transferring strategies from face-to-face communication. In another study, Peterson (2012) found out that students showed collaborative interaction by peer-scaffolding for lexis and correction, and showed extensive use of positive politeness for supportive atmosphere. $\mathrm{He}$ concluded that Second Life can be a venue for learner-centered social interaction and for developing learner autonomy.

As the literature indicates, teachers and researchers have tried to incorporate Second Life in foreign or second language instruction in various ways, but there have been few studies that have attempted to examine the effects of task type on the use of Second Life environment by ESL students. In order to enrich the literature, the present study has two research questions:

1. What are the effects of task types on ESL learners' negotiation of meaning in Second Life?

2. How do students use affordances of Second Life while they are engaging in the tasks?

\section{Methods}

\section{Participants}

Intact groups were used because the study was part of a regular classroom activity. 21 students from two High-Intermediate classes and 13 students from a Low-Intermediate class from an ESL institute in the U.S. participated in this study. They were all taking a "Speaking and Listening" class. Of the 34 students, 22 were female and 12 were male. The mean age of High-Intermediate students was 26.5 years, and that of Low-Intermediate was 24 years. They were familiar with voice-chatting using MSN or Skype, but no one had used Second Life. Each student was assigned to a group of two or three people for each task. To save time, after all students had created an account in Second Life, their avatars were "located" in a certain place as a group of two or three. In this way, when students logged on they would meet their team members' avatars immediately. For the same type of task, the same students were assigned.

\section{Tasks}

Because the present study is to see how students negotiate during communication breakdowns, the tasks followed Pica et al.'s (1993) typology: jigsaw, decision-making, and discussion, a spectrum from most to least facilitative communication tasks adopted from previous studies (Blake, 2000; Peterson, 2006; Smith, 2003). Each Jigsaw or Decision-making task was followed by a discussion task. For example, a Jigsaw task asked the students to put different pictures in order, used in studies by Smith $(2001,2003,2004)$ and Peterson (2006). In groups of three, a Jigsaw task let each student have two different pictures; students needed to figure out the correct order of the six pictures to make a story. One Decision-making task involved a discussion of appropriate gifts to a host family. In groups of three, students had a different set of gift items, 
and had to decide which gift would be good for which person. The topics for Discussion tasks were varied: "What is the best holiday in your country?" and "Talk about the gift-giving custom in your country."

Each Jigsaw and Decision-making task was implemented twice with different content, but the group remained the same for both implementations to ensure some familiarity among the group members (Plough \& Gass, 1993; Zuengler, 1993). To facilitate active participation, each task was designed as two-way tasks, assigning each person a particular role. Moreover, students were required to use only voice-chat to communicate. In order to avoid task effects, one class of the High-Intermediate groups started with Jigsaw tasks first, and the other class started with Decision-Making tasks first. Because there was only one Low-Intermediate class, this class started with Jigsaw tasks, which followed the order of other task-based SCMC studies (Blake, 2000; Peterson, 2006; Smith, 2003).

\section{Procedures}

The students participated in total of six 45-minute sessions. Two workshops were conducted before they engaged in the official tasks. The first workshop was designed to give basic information about Second Life, and to give students time to practice basic functions of Second Life. The second workshop focused on use of voice-chat and avatar gestures and movement. After the training workshops, two sessions of each type of task were conducted, either Jigsaw or Decision-making tasks. A discussion task followed either the Jigsaw or Decision-making task.

"Camtasia"" was used to capture students' voices as well as all movements they made on screen through their avatars. Recording what was happening in Second Life through Camtasia meant that a recording avatar had to be present in every "room" (that is, every group) in which the students were interacting. Thus, five recording avatars were created and appeared in each group's virtual meeting space. In order for these recording avatars to remain as unobtrusive as possible and to reduce the effects of researcher presence, the recording avatars were made to look like small boxes that remained stationary (see Figure 1). I, as the researcher, acted as the lab instructor and monitored the class from the lab where the students were working. A colleague monitored and recorded all avatar movements and voices from a computer lab at a distance.

In terms of the online space in which the students engaged in the tasks, an open region to public was chosen. There were many rooms or open places with sofas and tables for the group work. To minimize confusion and misunderstanding, each team was allocated to one small space in the region before they started. Thus, each team was in a different virtual place, being separated by about 20 virtual feet, to allow for the least interference in voice chat. Moreover, the number of each team was limited to two or three people.

\footnotetext{
${ }^{1}$ For more information, see: http://www.microsoft.com/hardware/digitalcommunication/productdetails.aspx?pid=006
} 


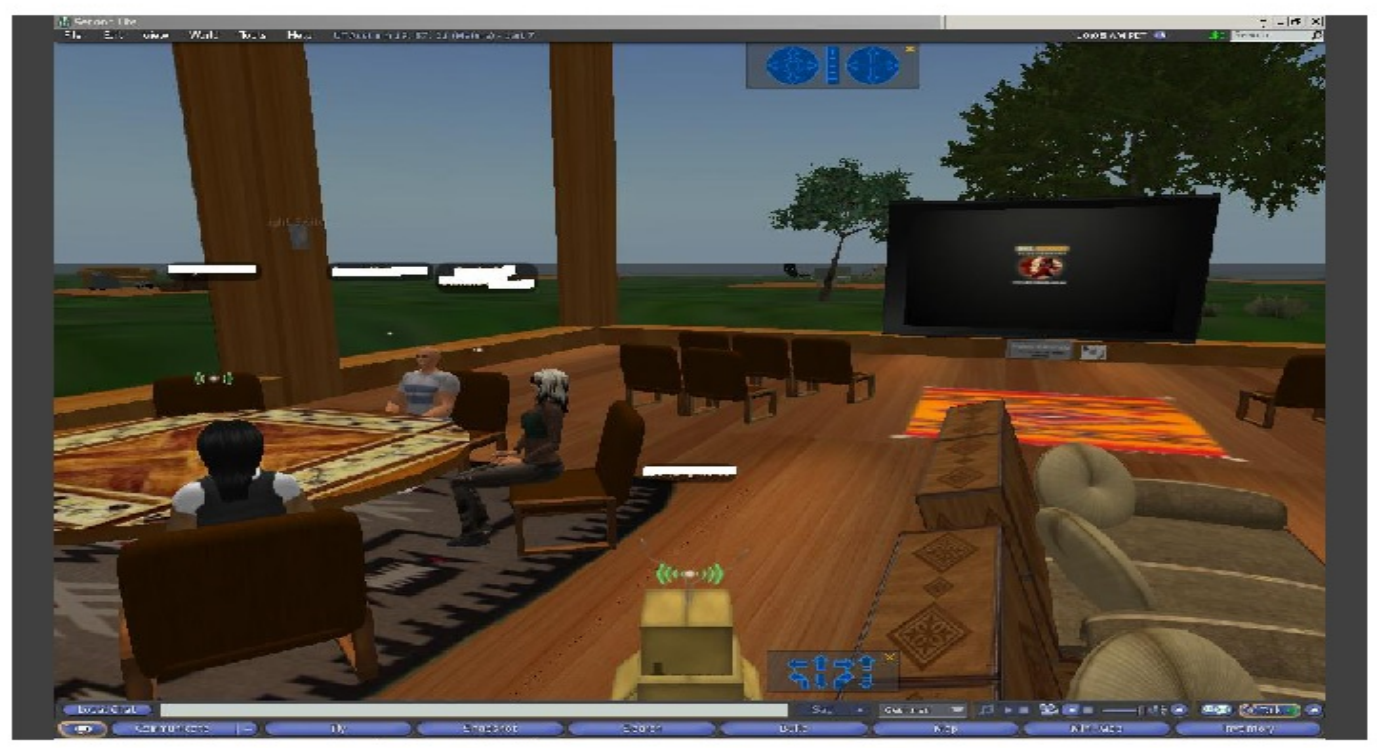

Figure 1. Snapshot of Second Life with the Researcher's Avatar

\section{Data Analysis}

For the overall process of the data analysis, I began by watching all 20 recorded files by Camtasia. Each file contained the students' voice-chat and recorded screen of each team in terms of avatar movement, gestures, or text-chat in Second Life. Then, I followed the steps of open coding, axial coding, and selective coding. During open coding, I classified emerging categories with a close examination of the data, especially looking for similarities and differences of each task type and level. During axial coding, I reassembled data that I had selected during open coding, searching for relations among categories to find bigger categories for more precise and complete explanations about the research questions. During the process of selective coding, I integrated and refined categories in order to represent the main themes.

Regarding students' interaction, the basic unit of analysis was the utterance. To show how ESL students solved their comprehension problems from an interactional perspective, I adopted negotiation of meaning (NOM) routine by Varonis and Gass (1985). It consists of Trigger (T) and Resolution (R) elements. A resolution consists of an Indicator (I), a Response (R), and a Reaction to the Response (RR). The trigger is what the speaker says to the hearer. The hearer has two immediate choices: to ignore or to react to the trigger. In the second part (Resolution), an indicator is what the hearer says to the speaker to "push down" the conversation. The third element, Response, is the speaker's response to the indicator of non-understanding. The fourth element is optional, and involved the reaction to the response (RR). For example,

T Dylan: He look like a country boy.

I Jasmine: So you...you.. you can see one guy in the garage?

R Dylan: Yeah..one...one...one boy..one guy.

RR Jasmine: Uh... 
In this excerpt, Jasmine asked a question after Dylan's utterance that acted like a confirmation check and then Dylan provided an answer as a response to indicator. Then, Jasmine said 'Uh,' as a reaction to Dylan's response.

\section{Results and Discussion}

Overall, negotiation of meaning routines were mostly caused by lexical problems; this finding corresponds to previous studies of task-based SCMC (Lee, 2001; Fernandez Garcia \& MatinezArbelaiz, 2002; Blake, 2000; Smith, 2003, 2004), and the student used three types of NOM strategies: Comprehension check, confirmation check, and Clarification request. In terms of task effect, High-Intermediate students had more negotiation of meaning in the Decision-making task than in the Jigsaw task, which corresponds to studies by Smith $(2003,2004)$ and Peterson (2006) mainly for lexical meaning. This finding contrasts with those of Blake (2000) and Pica et al. (1993) that Jigsaw tasks elicited more negotiation of meaning. Because I adopted the tasks that were used by Smith $(2003,2004)$ and Peterson (2006), this may explain why I obtained the same result, indicating that it is not only task types that affect students' communication but other factors such as content of the task and level of proficiency, that may play a bigger role in eliciting negotiation. In other words, task-induced saliency by Smith (2003) and task difficulty by Pellettieri (2000) explain the results well. For the High-Intermediate students, the Jigsaw tasks were easier than the Decision-making tasks, as the former required only simple picture descriptions while the latter required them to use creative thinking. They had to think of "why" a particular item was appropriate to this person and sometimes they had to explain where and how to use this item. Cognitive overload can be another reason. While they were doing Jigsaw tasks, they had to look at the handout for the picture description, and apparently they did not look much at the monitors. For them, looking at both the monitor and the handout at the same time may have been too much. Thus, they did not have the chance to see others' avatars or to worry much about the Second Life environment, lowering their interest and focusing on only task completion. Unlike Jigsaw tasks, during Decision-making tasks, it was more possible to look the monitor and at others' avatars, and thus, may have increased their interest to talk.

For the Low-Intermediate students, the team that successfully completed the task had more negotiation of meaning than the team that did not complete the task, and more than the team that successfully completed the task of High-Intermediate students. This might be explained by task difficulty. As Pellettieri (2000) suggested, if students have difficulties caused by their lack of knowledge, especially knowledge of lexicon items, they are likely to have communication breakdowns, and so need to negotiate meaning. The task may be difficult for Low-Intermediate students, and led to more negotiation of meaning than for the successfully completed team of High-Intermediate. For the incomplete team of Low-Intermediate students, the difficulty of the task proved daunting to the students' motivation, and they ultimately failed to complete the task with limited verbal negotiation, instead relying on showing each other directly which item they meant.

As for the student's reliance on the affordances of Second Life, they found a way to make use of the many features of the program even though the task did not necessarily encourage such use. For example, students sometimes displayed good use of compensatory actions, or adaptive behavior (Peterson 2010), such as using the text messaging function to clarify some words that seemed to be causing communication problems because of their pronunciation or lack of word knowledge: 
Grace: and..the other thing is stampler (stapler) ${ }^{2}$... stampler..

John: Stampler..

Austin: Stampler? I, I don’t know.

Grace: Stampler..do you know?

John: Ah...

Grace: stampler, S..T..A..

Austin: It's like what?

Grace: P..L..E..R

\section{stapler (Texting)}

John: It is for step paper.

Grace: Stapler...when you..when you...

Austin: Ah! Ok.

Grace: together the...

Austin: for bind sheets?

Grace: Yeah..yeah..

\section{John: it is for step papers (Texting)}

Austin: ok..ok.. very..useful advice.

As Grace mispronounced the word "Stampler," Austin did not get it at first. So, Grace spelled out the word and then texted the word to give him a correct spelling. Moreover, John used text messaging at the end of the excerpt: "it is for step papers." Even though John said that sentence in the middle of the excerpt, nobody seemed to understand it or hear. In order to get others' attention or to make others understood the meaning of the word, he used a text messaging.

Moreover, some team members played with their avatars during the Discussion task, a task that allowed them less restrictions than the Jigsaw or Decision-making tasks. Some team members even finished the Discussion task and simply played with their avatars or explored the Second Life environment using walking, jumping, and flying functions. This resulted in more off-task conversation. On the contrary, none of the students used avatars during the Jigsaw task, probably because of the strictness of the task. Thus, avatar use may also be affected by the structure of the task where students used more avatar movements in less facilitative task types (i.e., Decision-

${ }^{2}$ Grace pronounced 'Stapler' as 'Stampler'. 
making and Discussion task). Moreover, the students used only very limited gestures and movements with their avatars such as jumping, walking, and flying. This corresponds to Peterson's $(2005,2006)$ studies that learners used some of the movement features only at the initial introduction and that lack of time to practice caused limited use of avatars. Therefore, enough training time for the variety of the avatar functions may increase students' use of avatars, and ultimately this unique feature may enhance students' engagement and enjoyment (Peterson, 2012). Furthermore, the affordances of Second Life, at least in part, can explain telepresence. In fact, both those teams who were successful and those who were unsuccessful in terms of setting telepresence maximally used the affordances of Second Life. The successful teams saw the chairs and a table, and they did not have any distracting objects in the room. The setting in Second Life was very similar to a face-to-face classroom setting, so students simply made their avatars sit without any hesitation at the beginning. They used the affordances of Second Life in their own way. However, the unsuccessful teams had more distracting objects near their avatars in an open space, which was a bit different from their classroom environment. Perhaps this is what led them to want to explore the affordances of Second Life, which had the effects of not establishing telepresence.

\section{Conclusion}

This study investigated task effects on ESL students' negotiation of meaning in Second Life, and how students used affordances of Second Life during the official tasks. Lexical problems were the major reason of the negotiation, and Decision-making task elicited more negotiation of meaning routines than Jigsaw task in the High-intermediate groups. For the Low-intermediate group, successfully completed team had more negotiation of meaning routines than the incomplete team. Students used very limited functions of the avatar movements and gestures, and no avatar movements were observed during Jigsaw task. Students sometimes devised a way of compensating the difficulties such as texting, and teams that set telepresence were successful in completing the tasks. Thus, even though students were allowed to use restricted functions of Second Life with basic training, good evidence for SLA were observed such as negotiation of meaning, collaboration, and avatar use for telepresence. Therefore, some practical implications can be drawn based on the findings. For more negotiation of meaning, tasks should be a little bit more difficult than the students' current level, especially for the advanced students, and the topics or content of the tasks should be interesting in order to better motivate students to involve the task completion. Assigning a group leader might be helpful for students in organizing or approaching the task in a more structured way. Moreover, assigning role may have different effects on their avatar use (Wigham \& Chanier, 2013), so students may have an opportunity use different and various kinds of movements and gestures of the avatars. Sufficient training is a prerequisite to allow students use full range of the functions and to avoid technical problems for better interaction in Second Life. Moreover, discussion tasks or less structured tasks may enhance students' use of avatars by giving them freedom to interact. Or more authentic tasks may be effective. For example, if students are asked to find a native speaker of English in Second Life and have to ask the native speaker's opinion on a topic, they will not only meet a native speaker of English but also have to use Second Life functions. The experience might enhance students' intrinsic interest for learning English and for using Second Life as a future English learning tool (Kuriscat \& Luke, 2009). In addition, if students have become adept at dealing with computers, other resources such as online materials, audio or video podcasts, webpages, and PowerPoint presentations in Second Life can be incorporated (Cooke-Plagwitz, 
2008; Deutschmann et al., 2009). Second Life also can allow students to engage in more authentic tasks than the classroom environment, even more structured types of tasks. Because Second Life simulates many places that resemble the real world such as restaurants, cafes, and major cities like New York, if students are asked to find information about these places, they can teleport to the place and find appropriate answers. Moreover, once there they may meet someone who is also visiting the same virtual space and have a conversation. These kinds of activities might enhance students' motivation to learn and enhance the authenticity not only of the environment but also of language use per se.

More real life setting in Second Life without distracting objects might be better in enhancing telepresence because setting a telepresence may enhance students' sense of "being together" in cyber places and result in successful task completion. In addition, the imaginative or game-like environment with avatars may have a potential to create a flow of learning (Csikszentmihalyi, 1991) for students, depending on the level and task. Also, by helping each other in terms of avatar movements or changing appearance of avatars, the students could have more opportunities for collaboration.

Limitations of this study include limited time for practice and unexpected technological problems. Also, using Second Life as a classroom activity requires much effort and preparation for teachers and students. Nevertheless, considering that there is a growing body of research on Second Life in various content areas, and that new technologies are themselves changing and at the same time change radically education, this study is important for its examination of a new technology, Second Life, to provide pedagogical benefits to ESL/EFL teachers and students.

\section{References}

Barab, S., Thomas, M., Dodge, T., Carteaux, R., \& Hakan, T. (2005). Making learning fun: Quest Atlantis, a game without guns. Educational Technology Research and Development, 53(1), 86-107.

Blake, R. (2000). Computer-mediated communication: A window on L2 Spanish interlanguage. Language Learning \& Technology, 4(1), 20-36.

Bugeja, M. J. (2007). Second thoughts about Second Life. The Chronicle of Higher Education, 54(2), Chronicle Careers.

Chen, D. (2010). Enhancing the learning of Chinese with Second Life. Journal of Technology and Chinese Language Teaching, 1(1), 14-30.

Cooke-Plagwitz, J. (2008). New directions in CALL: An objective introduction to Second Life. CALICO Journal, 25(3), 547-557. 
Craig. E. (2007). Meta-perspectives on the metaverse: A blogsphere debate on the significance of Second Life. Paper presented at ED-MEDIA World Conference on Educational Multimedia, Hypermedia \& Telecommunications, Vancouver, Canada.

Csikszentmihaly, M. (1991). Flow: the psychology of optimal experience. New York: Harper Collins.

Dalgarno, B. (2002). The potential of 3D virtual learning environments: A constructivist analysis. Electronic Journal of Instructional Science and Technology, 5(2), 1-19.

Dede, C., Clarke, J., Ketelhut, D., Nelson, B., \& Bowman, C. (2005). Fostering motivation, learning, and transfer in multi-user virtual environments. Paper presented at the American Educational Research Association Conference, Montreal.

Deutschmann, M., Panichi, L., \& Molka-Danielsen, J. (2009). Designing oral participation in Second Life - a comparative study of two language proficiency courses. ReCALL, 21(2), 206-226.

Dickey, M. (2005). Three-dimensional virtual worlds and distance learning: Two case studies of Active Worlds as a medium for distance education. British Journal of Educational Technology, 36(3), 439-451.

Dickey, M. D. (2011). The pragmatics of virtual worlds for K-12 educators: Investigating the affordances and constraints of Active Worlds and Second Life with K-12 in-service teachers. Educational Technology Research \& Development, 59(1), 1-20.

Fernandez-Garcia, M., \& Martinez-Arbelaiz, A. (2002). Negotiation of meaning in nonnative speaker-nonnative speaker synchronous discussions. CALICO Journal, 19, 279-294.

FitzGerald, S. (2007). Virtual worlds - What are they and why do educators need to pay attention to them? Paper presented at E-learning Networks June Online Event.

Gerhard, M., Moore, D., \& Hobbs, D. (2004). Embodiment and copresence in collaborative interfaces. Human-Computer Studies, 61(4), 453-480.

Grant, S., \& Huang, H. (2010). The integration of an online 3D virtual learning environment into formal classroom-based undergraduate Chinese language and culture curriculum. In D. B. $\mathrm{Xu}$, J. Da \& P. Zhang (Eds.), Proceedings of the $6^{\text {th }}$ International Conference and Workshops on Technology and Chinese Language Teaching in the $21^{\text {st }}$ Century (pp. 9299), Ohio State University.

Henderson, M. Huang, H., Grant, S., \& Henderson, L. (2009). Language acquisition in Second Life: Improving self-efficacy beliefs. Proceedings ASCILITE Auckland 2009, 464-474.

Hislope, K. (2008). Language learning in a virtual world. The International Journal of Learning, $15(11), 51-58$.

Hismanoglu, M. (2012). Integrating Second Life into an EFL classroom: A new dimension in foreign language learning and teaching. International Journal on New Trends in Education and Their Implications, 3(4), 100-111. 
Jee, M. (2010). ESL students' attitudes toward tasks in Second Life, The Society for Teaching English through Media Journal, 11(2), 183-205.

Jee, M. (2011). ESL Students' interaction in Second Life: Unofficial task periods activities. Korean Journal of Applied Linguistics, 27(4), 55-80.

Kemp, J., \& Livingstone, D. (2006). Putting a Second Life "metaverse" skin on learning management systems. In D. Livingstone \& J. Kemp (Eds.), Proceedings of the Second Life education workshop at the Second Life community convention (pp. 13-18). San Francisco: University of Paisley, UK.

Kuriscak, L. M., \& Luke, C. L. (2009). Language learner attitudes toward virtual worlds: An investigation of Second Life. In L. Lomicka, \& G. Lord (Eds.), The next generation: Social networking and online collaboration in foreign language learning (pp.173-198). San Marcos, TX: CALICO.

Lamb, G. M. (2006). Real learning in a virtual world. Christian Science Monitor. Retrieved from http://www.csmonitor.com/2006/1005/p13s02-legn.html

Laufer \& Hulstijn (2001). Incidental vocabulary acquisition in a second language: the construct of task-induced involvement. Applied Linguistics, 22(1), 1-26.

Lee, L. (2001). Online interaction: negotiation of meaning and strategies used among learners of Spanish. ReCALL, 13, 232-244.

New Media Consortium and EDUCAUSE Learning Initiative. (2007). The horizon report. Retrieved from http://www.nmc.org/pdf/2007_Horizon_Report.pdf

Ornberg, T. (2003). Linguistic presence on the Internet: Communication, worldview and presence in online virtual environments. Unpublished thesis, University of Umea.

Pellettieri, J. (2000). Negotiation in cyberspace: the role of chatting in the development of grammatical competence. In R. Kern, \& M. Warschauer (Eds.), Network-based language teaching: concepts and practice (pp.59-86). Cambridge: Cambridge University Press.

Peterson, M. (2005). Learning interaction in an avatar-based virtual environment: preliminary study. PacCALL Journal, 1(1), 29-40.

Peterson, M. (2006). Learner interaction management in an avatar and chat-based virtual world. Computer Assisted Language Learning, 19(1), 79-103.

Peterson, M. (2010). Learner participation patterns and strategy use in Second Life: an exploratory case study. ReCALL, 22(3), 273-292.

Peterson, M. (2012). EFL learner collaborative interaction in Second Life. ReCALL, 24(1), 2039.

Pica, T., Kanagy, R., \& Falodun, J. (1993). Choosing and using communication tasks for second language research and instruction. In G. Crookes, \& S. Gass (Eds.), Tasks and seconlanguage learning (pp. 9-34). Clevedon, UK: Multilingual Matters. 
Plough, I., \& Gass, S. M. (1993). Interlocutor and task familiarity: Effects on interactional structure. In G. Crookes \& S. M. Gass (Eds.), Tasks and language learning: Integrating theory and practice (pp. 35-56). Clevedon, UK: Multilingual Matters.

Schiller, S. Z. (2009). Practicing learner-centered teaching: Pedagogical design and assessment of as Second Life project. Journal of Information Systems Education, 20(3), 369-381.

Schroeder, R. (2002). Social interaction in virtual environments: key issues, common themes, and a framework for research. In R. Schroeder (Ed.), The social life of avatars: presence and interaction in shared virtual environments (pp. 1-16). London: Springer.

Smith, B. (2001). Taking students to task: task based computer-mediated communication and negotiated interaction in the ESL classroom. Unpublished doctoral dissertation, University of Arizona, Tucson.

Smith, B. (2003). Computer-mediated negotiated interaction: An expanded model. The Modern Language Journal, 87, 38-57.

Smith, B. (2004). Computer-mediated negotiated interaction and lexical acquisition. Studies in Second Language Acquisition, 26, 365-398.

Sykes, J. M., Oskoz, A., \& Thorne, S. L. (2008). Web 2.0, synthetic immersive environments, and mobile resources for language education. CALICO Journal, 25(3), 528-546.

Sykes, J. M. (2009). Learner requests in Spanish: Examining the potential of multiuser virtual environments for L2 pragmatics acquisition. CALICO Monograph Series, 8, 199-234.

Varonis, E. M. \& Gass, S. (1985). Non-native/non-native conversation: A model for negotiation of meaning. Applied Linguistics, 6(1), 71-90.

Ventrella, J. J. (2011). Virtual Body Language - The History and Future of Avatars: How Nonverbal Expression is Evolving on the Internet. ETC Press.

Wang, F. \& Burton, J. K. (2012). Second Life in education: A review of publications from its launch to 2011. British Journal of Educational Technology, 44(3), 357-371.

Wang, C. X., Lefaiver, M. L., Wang, Q, \& Hunt, C. (2011). Teaching in an EFL program in Second Life: Student teachers' perspectives and implication, Journal of Educational Technology Development and Exchange, 4(1), 27-40.

Wigham, C. R., \& Chanier, T. (2013). A study of verbal and nonverbal communication in Second Life-the ARCHI21 experience. ReCALL, 25(1), 63-84.

Zuengler (1993). Encouraging Learners' Conversational Participation: The Effect of Content Knowledge. Language Learning, 43(3), 403-432.

\section{Author}

Min Jung Jee earned Ph.D. in Foreign Language Education from the University of Texas at Austin. She has taught all levels of Korean language courses at UT Austin as a lecturer since 
2010. Her research interests are technology assisted language learning and teaching, learner affect, and heritage learners. Email: minjungjee@gmail.com

(c) (1)

This work is licensed under a Creative Commons Attribution 3.0 License. 